Studenckie Zeszyty Naukowe

Zeszyt $25 \cdot$ rok XVII $\cdot 2014$

\author{
Paulina Krukowska, Łukasz Bolesta
}

\title{
DIRECT AND INDIRECT EFFECT IN EU CONSUMER LAW IN THE LIGHT OF “FACCINI DORI”, “DILLENKOFER” AND THE OTHER EU CASES.
}

The European Union of 28 countries has almost half a billion potential consumers. The Member States have progressively developed measures aimed at safeguarding the specific interests of these consumers who play a vital economic and political role in society. Starting in the mid-1970s, the EU has endeavoured to harmonise these national measures in order to guarantee European citizens the same high level of protection throughout the single market ${ }^{1}$.

In any system of consumer protection, problems of securing effective access to justice loom large. Consumers are understandably reluctant to convert complaint into formal proceedings, especially where their loss is relatively small ${ }^{2}$. Many consumers have only a limited grasp of the intricacies of the law. Taking legal action is in any event costly, slow and a source of stress. The Court of Justice has to some extent come to consumer's rescue. The Court has famously developed the constitutional impact of EU law within the national legal order far beyond that envisaged by the explicit terms of the Treaty ${ }^{3}$. In certain circumstances an unimplemented Directive may generate legal effects within the national system which benefit the individual, including the consumer.

The text of article 288 TFEU stipulates that a Directive is „binding, as to the result to be achieved, upon each Member State to which it is addressed, but shall leave to the national authorities the choice of form and methods" ${ }^{4}$. Directives appear incapable of direct effect, for their impact is conditional on national

${ }^{1}$ E.g. B. De Witte, Direct Effect, Primacy and the Nature of the Legal Order" in P. Craig and G. de Burca (eds), The Evolution od EU Law, 2nd edn, Oxford: OUP, 2011 r., p. 56.

${ }^{2}$ R. Schulze and others, European Consumer..., op.cit., p. 45.

${ }^{3}$ Ibidem, p. 87.

${ }^{4}$ P. Craig, The Legal Effect of Directives; Policy, Rules and Exceptions, Oxford 2009, p. 66. 
implementing measures. In unimplemented guise they seem inapt for judical enforcement.

Indirect effect describes a situation where national courts are required to interpret national law in line with an unimplemented or badly implemented directive, as opposed to ignoring national law in preference to the directive as occurs when direct effect is invoked. Indirect effect arises from the failure of a member state to implement a directive - either correctly or at all — but where direct effect cannot apply because the party against whom the directive is sought to be enforced is a private entity or otherwise fails to meet the conditions which would give the directive direct effect. In Von Colson and Kamann $v$ Land Nordrhein-Westfalen, the ECJ ruled that national courts should interpret national law in line with the directive, "in so far as it is given discretion to do so under national law". While Von Colson dealt with a situation where a member state had failed to implement a directive correctly, in Marleasing $v$ La Comercial Internacional de Alimentacion the ECJ extended indirect effect to situations where the member state concerned had not implemented the directive at all. ${ }^{6}$

Direct effect is the principle of European Union law according to which provisions of Union law may, if appropriately framed, confer rights on individuals which the courts of member states of the European Union are bound to recognise and enforce. Not explicitly stated in any of the EU Treaties, the principle of direct effect was first established in relation to provisions of those treaties by the European Court of Justice in Van Gend en Loos v. Nederlandse Administratie der Belastingen ${ }^{7}$. Direct effect has subsequently been loosened in it is application to treaty articles and the ECJ has expanded the principle, holding that it is capable of applying to virtually all of the possible forms of EU legislation, the most important of which are regulations, and in certain circumstances to directives.

The ECJ first articulated the doctrine of direct effect in the case of Van Gend en Loos, ${ }^{8}$ the European Court of Justice laid down the criteria (commonly referred to as the "Van Gend criteria") for establishing direct effect. The EU article provision must:

- be clear,

- be a negative, rather than positive obligation

- unconditional,

- containing no reservation on the part of the member state, and

- not dependent on any national implementing measure ${ }^{9}$.

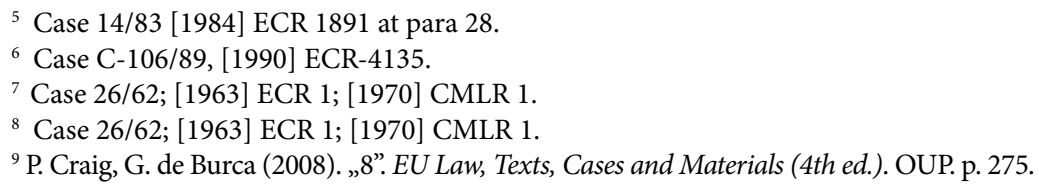


If these criteria are satisfied, then the right or rights in question can be enforced before national courts. Of course whether or not any particular measure satisfies the criteria is a matter of EU law to be determined by the EU Courts.

In Van Gend en $\operatorname{Loos}^{10}$ it was decided that a citizen was able to enforce a right granted by European Community legislation against the state - the question of whether rights could be enforced against another citizen was not addressed. In Defrenne v. SABENA ${ }^{11}$, the European Court of Justice decided that there were two varieties of direct effect: vertical direct effect and horizontal direct effect, the distinction drawn being based on the person or entity against whom the right is to be enforced. Vertical direct effect concerns the relationship between EU law and national law - specifically, the state's obligation to ensure its observance and its compatibility with EU law, thereby enabling citizens to rely on it in actions against the state or against public bodies; an "emanation of the state" as defined in Foster v. British Gas plc ${ }^{12}$.

Horizontal direct effect concerns the relationship between individuals (including companies). If a certain provision of EU law is horizontally directly effective, then citizens are able to rely on it in actions against each other. Directives are usually incapable of being horizontally directly effective. Certain provisions of the treaties and legislative acts such as regulations are capable of being directly enforced horizontally.

Direct effect is applicable when the particular provision relied on fulfils the Van Gend en Loos criteria. It is therefore applicable in the case of treaty articles (Van Gend en Loos was a claim based on a treaty article), in which case it can be both vertically and horizontally directly effective.

However, the Court is not prepared to allow a private individual to rely on an unimplemented Directive other than in proceedings where the other party is the state. This is vertical direct effect, of which Directives are capable, but Directives are not horizontally directly effective, that is they may not be invoked directly in relations between private parties before national courts. The Court's refusal to countenance the horizontal direct effect of Directives was established in Marshall v. Southampton Area Health Auhority ${ }^{13}$, a case arising in the sphere of sex discrimination. The principal objection to attributing horizontal direct effect to an unimplemented Directive was the Court's perception that it is the state, not a private individual, which is at fault and that it would accordingly be improper to interpret the constitutional reach of the unimplemented Directive

\footnotetext{
${ }^{10}$ Case 26/62; [1963] ECR 1; [1970] CMLR 1.

${ }^{11}$ Case 2/74 [1974] ECR 631.

${ }^{12}$ Case C-188/89 [1990] ECR I-3313.

${ }^{13}$ Case 152/84 [1986] ECR 723.
} 
in such a way as to impose obligations on an "innocent” private party. This is a significant problem for the customer. The customer wishing to rely on an unimplemented Directive will succeed where the supplier is the "state", which for these purposes is broadly interpreted to include local authorities ${ }^{14}$ and even private entities which possess special powers beyond those which result from the normal rules applicable in relations between individuals ${ }^{15}$. However, beyond the reach of the public sector, even broadly defined. Directives are incapable of direct effect. Typically the protection envisaged by an EU Directive in the consumer field will relate to private relationships between consumer and supplier. Accordingly the consumer will remain dependent on faithful national implementation for legal protection $^{16}$.

National courts shall secure the "indirect effect" of a Directive applies to "national law, whether the provisions concerned pre-date or post-date the Directive" ${ }^{\prime 17}$. The national court must consider national law as a whole, not simply measures transposing a particular Directive. The Court explained in Pfeiffer that the requirement that national law be interpreted in conformity with EU law is "inherent in the system of the Treaty, since it permits the national court, the matters eithin its jurisdiction, to ensure the full effectiveness of EU law"18. And logically this is treated as a persisting obligation. Even in the event of accurate implementation it is expected that national courts will draw on the Directive where national authorities apply implementing national measures in a manner incompatible with $\mathrm{it}^{19}$. Through this technique an unimplemented or improperly implemented Directive can penetrate the legal order. The Court of Justice added means of individual legal protection in Francovich v. Italian State ${ }^{20}$, a case which arose in the sphere of a Directive concerning employment protection but which expressed a principle of wider application. The need to secure the full effectiveness of EU rules it decided that EU law recognises that individuals may be able to obtain redress before a national court when rights are infringed by a breach for which a Member State can be held responsible. This principle of state liability is "inherent in the system of the Treaty" - the same claim the Court made

\footnotetext{
${ }^{14}$ Case 103/88 Fratelli Costazo v. Milano [1989] ECR 1839.

${ }^{15}$ Case C-188/89 Foster v. British Gas [1990] ECR I-3133.

${ }^{16}$ R. Schulze and others, European Consumer..., op.cit., p. 98.

${ }^{17}$ Case C-106/89 Marleasing v. La Comercial Internacional de Alimentacion [1990] ECR I-4135.

${ }^{18}$ Joinded Cases C-397/01 to C-403/01 Pfeifer and Others [2004] ECR I-8835, para. 114.

${ }^{19}$ Case C-62/00 Marks and Spencer plc v. Commissioners of Customs and Excise [2002] ECR I-6325.

${ }^{20}$ Cases C-6, C-9/90 [1991]ECR I-5357.
} 
subsequently in Pfeiffer to justify the "indirect effect" od EU law before national courts. A Francovich claim is the most direct method of protection for the individual prejudiced by non-implementation of a Directive, although claims based on the direct and indirect effect of Directives are also still available. The "Francovich principle" has been used in the context of consumer protection. One can accordingly depict Francovich as a source of consumer rights against the state.

In Erich Dillenkofer et a v. Germany ${ }^{21}$ the Court concluded that consumers who had suffered loss when their package holiday organisers went insolvent were entitled to seek compensation from the German public authorities. The cirumstances of this case, which concerns an EU Directive 90/314 on package travel, package holidays and package tours are very similar those of Francovich. The Directive in question provides guarantees for a refund of money paid for package travel and repatriation in case of the organizer's insolvency. Although the prescribes period for the implementation of the Directive ended on December 31, 1992, it was not implemented in Germany until June 1994. The plaintiffs in the case had bought tour packages from a tour operator who became insolvent in 1993. As a result, the plaintiffs either never left for their destination or returned at their own expense. Due to the non-implementation of the Directive, the plaintiffs did not obtain any reimbursement for the losses they had suffered. Consequently, arguing that if the Directive had beed implemented within the prescribed period they would have been protected against the insolvency of the tour operator from whom they had purchased the package tour, the plaintiffs brought an acion against Germany for damages. The German court made a reference to the ECJ under article 177 for a preliminary ruling on the interpretation of Community law ${ }^{22}$.

The Dillenkofer judgment is important for two principal reasons. First, it further develops European Court of Justice jurisprudence concerning Member States non-contractual liability. Article 215 of the Treaty of Rome makes the Community institutions subject to non-contractual liability, but it fails to impose the same liability on Member States. It has been for the ECJ in its role as "the guardian of the Treaty" under article 164 to fill this vacuum. The Dillenkofer judgment is one in a series of judgments, rendered by the ECJ in the 1990's, which lay the groundwork for Member States non-contractual liability. The Dillenkofer judgment is also important because it emphasizes the role of directives as legislative instruments ${ }^{23}$.

${ }^{21}$ Joined Cases C-178/94, C-179/94, C-188/94, C-189/94 and C-1990/94 [1996] ECR I-4845.

${ }^{22}$ P. Craig, The Legal..., op.cit., p. 78.

${ }^{23}$ R. Schulze and others, European Consumer Law, Oxford 2002, p. 96. 
The interesting part of the Dillenkofer judgment is the part dealing with the conditions under which a Member State can be held liable for damages for a breach of Community law. The Court reiterated the three conditions laid down in the Francovich judgement: a directive should confer rights on individuals, the content of the rights should be identifiable, and there should be a casual link between the infringement and the damage ${ }^{24}$. In Dillenkofer the Court added to the definition of sufficiently serious. The Court finds that when a Member State fails to take adequate measures to implement a directive in the prescribed period, this constitutes per se a serious or manifest and grave, breach of Community law. This serious breach gives rise to a right of reparation for individuals who have suffered injury. The Dillenkofer judgment has again shown that companies which are confronted with barriers to trade caused by a Member State's failure to apply Community law will find strong support from the Court of Justice in Luxembourg. As long as companies doing business in the EU cannot rely directly on a non-implemented directive to enforce their legal rights against other companies (in the other words as long as the ECJ does not recognize "horizontal direct effect for directives") one of the strongest means available is to claim damages from the infringing Member State. To this end, the Dillenkofer judgment has made a valuable contribution.

This pattern of legal protection for the individual is far more intricate than anything explicity recognised by the Treaty, but one element still remains absent: the horizontal direct effect of a Directive ${ }^{25}$. An unimplemented Directive is not capable of generating rights which one private individual is able to enforce against another private individual. The Court's refusal to countenance horizontal direct effect of Directives has been subjected to criticism that it indermines effective legal protection and that it leads so inequality of citizens before the law, since the impact of Directives varies across the territory of the Union depending on the patterns of implementations state by state. But the Court is unmoved. Its ruling in Faccini Paola Dori v. Recreb Sri ${ }^{26}$ was delivered in the context of the non-implementation of a Directive in the consumer field and is therefore richly illustrative of the obstacles to consumer access to justice which flow from the Court's stance. Italy had failed to implement Directive 85/577 on "Doorstep Selling”. On Milan Railway Station, Ms Dori was lured into a contract covered by the Directive by a seller of educational material. Under the Directive, she should have been entitled to claim a right to withdraw from the deal and having "cooled off" she decided that she wished to exercise that right. Under Italian law no such

\footnotetext{
${ }^{24}$ S. Weatherill, EU Consumer Law and Policy, Cheltenham 2013, p. 288.

${ }^{25}$ S. Weatherill, EU ..., op.cit., p. 291.

${ }^{26}$ Case C-91/92 [1994] ECR I-3325.
} 
right existed. In a preliminary ruling, the Court adhered to Marshall and held that the Directive could not be directly effective in such circumstances ${ }^{27}$. Plainly Ms Dori was denied a right which she was supposed to enjoy under a Directive. A loophole in the practical vigour EU consumer protection law is exposed. The Court mentioned the obligation of the national court to interpret national law in the light of the Directive. A consumer in such circumstances simply wishes to exercise a right to withdraw from a contract, involving, if necessary a suitable defence to a claim for breach of contract where he or she refuses to pay sums due. This is effective method of protecting consumer rights and it is the effective method of securing observance of Directives evenly throughout the territory of the EU. Yet the Court in Dori asserted that the EU is not competent to enact by Directive obligations for individuals with immediate effects. The Directives of the Community are not capable of having "horizontal" direct effect ${ }^{28}$. The citizens of the Community are not able to enforce rights deriving from Directives in their dealings with other Community citizens. To sum up a Directives cannot itself impose obligations on an individual and cannot therefore be relied upon as such against an individual ${ }^{29}$.

Development of the legal protection of the consumer at the forum of European Communities has lasted over 30 years. Since that time consumer protection has developed, taking different forms. Above all EU cases, the threat of state liability for failing to transpose (consumer) Directives puts Member States under considerable pressure to fulfill their obligations to transpose ${ }^{30}$. What is more the experience of a claim of state liability on Germany has shown that a large number of consumers are clearly prepared to take on the risk of such a case. The decision in Dori therefore indirectly contributes towards improving the legal position of consumers by reducin the number of untransposed Directives.

In this matter, the discussion is particularly needed. It continues to draw new conclusions from the development of consumer protection over many years, be able to find the optimal solutions in the process of harmonization of European Consumer Law.

\footnotetext{
${ }^{27}$ R. Schulze and others, European Consumer... op.cit., p. 96.

${ }^{28}$ R. Schulze and others, European Consumer..., op.cit., p. 134.

${ }^{29}$ P. Craig, The Legal..., op.cit., p. 95.

${ }^{30}$ S. Weatherill, EU ..., op.cit., p. 211.
} 
Pobrane z czasopisma Studenckie Zeszyty Naukowe http://szn.umcs.pl Data: 26/04/2023 03:12:18

\section{DIRECT AND INDIRECT EFFECT IN EU CONSUMER LAW IN THE LIGHT OF „FACCINI DORI”, „DILLENKOFER” AND THE OTHER EU CASES}

Article focus on direct and indirect effect on EU consumer law. In this work we want to present the difference between indirect and direct effect in the light of "Faccini Dori", "Dillenkofer" and other EU cases. It will also be illustrated two varieties of direct effect: vertical direct effect and horizontal direct efffect and their relationship between EU law and national law. Then it will be studied the role of directives as legislative instruments. This will allow to have a final analyze and critic view on this all subject. 